УДК 140.8:784+159.9.01

\author{
Бобул Іван Васильович \\ завідувач кафедри естрадного співу \\ Київської муніципальної академії \\ естрадного та циркового мистеитва \\ Konuschenko65@gmail.com
}

\title{
СЕМАНТИЧНІ ВЛАСТИВОСТІ ВОКАЛЬНО-ЕСТРАДНОГО ВИКОНАВСТВА У КОНТЕКСТІ ТЕОРІЇ ІНТЕРПРЕТАЦІЇ
}

\begin{abstract}
Мета роботи постає як визначення комунікативної своєрідності та провідних текстологічних тенденцій, способів кодування $і$ символізації в вокальній естрадній творчості. Методологія дослідження зумовлена поєднанням герменевтичного, структуралістського, текстологічного та семіологічного підходів на основі цілісного вивчення явища вокально-естрадного виконавства. Наукова новизна роботи полягає у розкритті значення явищ інтерпретації та інтертекстуальності в сфері вокально-естрадного виконавства, у визначенні провідних форм інтерпретації в галузі естрадного мистецтва як театралізованої сценічної артистичної діяльності, у виявленні магістральної ролі особистості естрадного співака в організації інтерпретативної семантичної цілісності художньої форми естрадної вистави. Висновки. Вокально-естрадне виконавство має складну текстологічну організацію, що зумовлена особливою природою естрадного мистецтва. Воно передбачає високу інтертекстуальну активність провідної «дійової особи» - артиста-соліста, який стає семантичним стрижнем естрадно-сиенічної дії, суміщає декілька інтерпретативних функціональних планів, сприяє переродженню естрадної програми у сучасну квазі-сюжетну виставу з поетизованим образом людини у композиційному осередку.

Ключові слова: вокально-естрадне виконавство, інтерпретація, текст, інтертекстуальність, семантичні позиції, особистість співака, естрадно-сценічна дія.
\end{abstract}

Bobul Ivan Vasilyevich, head of the Department of Variety Singing Kyiv Municipal Academy variety and circus art

Semantic properties of vocal-pop performance in the context of the theory of interpretation

The purpose of the work appears as the definition of communicative originality and the leading textual tendencies, methods of coding and symbolization in vocal variety art. The methodology of the research is determined by a combination of hermeneutic, structuralist, textual and semiological approaches based on a holistic study of the phenomenon of vocal-pop performance. The scientific novelty of the work reveals the significance of the phenomena of interpretation and intertextuality in the field of vocal-pop performance, in determining the leading

(C) Бобул I. В., 2017 
forms of interpretation in the field of pop art as a dramatized stage artistic activity, in identifying the main role of the person pop singer in the organization of the interpretive semantic integrity of the artistic form of pop performance. Conclusions. Vocal-pop performance has a complex textual organization, which is determined by the special nature of pop art. It involves high intertextual activity of the leading «actor» - the soloist who becomes the semantic core of pop-stage action, combines several interpretive functional plans, contribute to the degeneration of the pop program in a modern quasi-story show with a poetic image of a person in the compositional cell.

Keywords: vocal-pop performance, interpretation, text, intertextuality, semantic positions, personality of the singer, pop-stage action.

Бобул Иван Васильевич, заведующий кафедрой эстрадного пения Киевской муниципальной академии эстрадного и циркового искусства

Семантические свойства вокально-эстрадного исполнительства в контексте теории интерпретации

Цель работы выступает как определение коммуникативного своеобразия и ведущих текстологических тенденций, способов кодирования и символизации в вокальном эстрадном творчества. Методология исследования обусловлена сочетанием герменевтического, структуралистского, текстологического и семиологического подходов на основе целостного изучения явления вокально-эстрадного исполнительства. Научная новизна работы заключается в раскрытии значения явлений интерпретации и интертекстуальности в сфере вокально-эстрадного исполнительства, в определении ведущих форм интерпретации в области эстрадного искусства как театрализованной сиенической артистической деятельности, в выявлении магистральной роли личности эстрадного певца в организации интерпретативной семантической целостности художественной формы эстрадного представления. Выводы. Вокально-эстрадное исполнительство имеет сложную текстологическую организацию, обусловленнную особой природой эстрадного искусства. Оно предполагает высокую интертекстуальную активность ведущего «действующего лииа» - артиста-солиста, который становится семантическим стержнем эстрадно-сценического действия, совмещает несколько интерпретативных функциональных планов, способствует перерождению эстрадной программы в современное квази-сюжетное представление с поэтизированным образом человека в композиционном иентра.

Ключевые слова: вокально-эстрадное исполнительство, интерпретация, текст, интертекстуальность, семантические позиции, личность певиа, эстрадно-сиеническое действие.

Актуальність теми дослідження. Можна вважати визнаним той факт, що теорія інтерпретації межує з теорією тексту; і та, й інша припускають герменевтичний підхід і покликані узгоджувати форму зі 
змістом, знакові побудови з їх значеннями, об’єктивні закономірності життя і свідомості з суб’єктивними факторами знання і розуміння. Отже в герменевтичний підхід вплітається семіотичний, який дозволяє вивчати певні явища як мовні, а в зв'язку з цим - розпізнавати і отримувати ті способи створення і з'єднання знакових конструкцій, які виконують функції смислового кодування, тобто ведуть до змістової експлікації явища. У мистецтвознавчому дослідженні дана взаємодія підходів і методичних принципів забезпечує контент-аналіз феноменів музичної творчості, у тому числі як характеристику репертуарних засад, з подальшим вивченням якісних параметрів творчого вибору, що визначають способи, форми інтерпретації, зумовлюють музично-виконавську форму в ії̈ цілому.

3 цієї точки зору, естрадне мистецтво, зокрема вокальне естрадне виконавство, є ще недостатньо вивченим та з'ясованим. Окремі його жанрові та композиційні складові, комунікативні аспекти розкриваються в тих роботах, які присвячені соціальній ролі естрадного мистецтва, його синтетичній природі та своєрідності виконавських завдань, що постають у даній сфері [3; 5-7; 9]. Але предметом поглибленої, з рисами герменевтичної, текстологічної розвідки естрадне вокальне виконавство ще не стало.

В теорії Р. Барта текст постає умовним часопростором, що здійснює множинність вираження смислу за допомогою певних структурних елементів та їх семантичних функцій. Розвиваючи підхід Барта, який передбачав розрізнення «малого» та «великого» текстів, тобто тексту твору та семіологічної організації мистецтва у його цілому, зазначимо, що, на відміну від твору, котрий має незначну символічність, встановлюючи однозначні відносини між структурним елементом та його композиційно-образною функцією, текст є відкритим до перетворень музичного матеріалу, вибудовує не лише лінійні, але й симультанні смислові зв'язки, виступає продуктом співтворчості автора та реципієнта, між якими розміщується виконавська інтерпретація. «Текст, - писав Р. Барт, - розуміється як простір, де йде процес утворення значень, тобто процес означування...» [1, 424]. Але треба додати, що в музичному тексті процес означення має безпосереднє звукове вираження, тобто текстуальним та смислово визначеним $є$ те, що звучить, те, що виконується, йде від майстерності та творчої свідомості виконавця.

Тому в музичній творчості текст, в його зумовленості процесом інтерпретації, є не лише системою зв'язків всередині твору (між різни- 
ми фрагментами твору), але й насамперед перехресними взаємодіями текстів різних творів, що породжує феномен цитації та алюзії, відображено в явищі та понятті інтертекстуальності, сприяє формуванню власних семантичних властивостей виконавської інтерпретації.

Мета роботи постає як визначення комунікативної своєрідності та провідних текстологічних тенденцій, способів кодування і символізації в вокальній естрадній творчості. Методологія дослідження зумовлена поєднанням герменевтичного, структуралістського, текстологічного та семіологічного підходів на основі цілісного вивчення явища вокально-естрадного виконавства.

Зауважимо, що кожна з художніх форм, у тому числі вокальне виконавство в галузі естрадної творчості володіє кодами як ходами до дешифрування та нового упредметнення смислу, прочитання на його основі цілісного повідомлення, отримання можливості його подальшої трансляції. Під кодом Р. Барт розумів надтекстову конфігурацію значень, яка може бути науковою, риторичною, історичною, соціокультурною, але завжди є кодом комунікації, тобто має, як головну, комунікативну мету та націленість на виконання певних співдій по досягненню необхідного рівня розуміння.

Код, що за У. Еко визначається як репертуар символів, може передбачати різні знакові критерії та орієнтири. Наближуючись до предмету дослідження, відзначимо, що до цього умовного знакового репертуару можуть належати час, спосіб створення тексту, жанровий характер залученого матеріалу, виконавське призначення, особистісний потенціал виконавської презентації даного матеріалу.

Виклад основного матеріалу. Потенційні можливості виконавської інтерпретації, пов'язані зі свободою вибору, є надзвичайно високими, існують як система ймовірностей, реалізація яких пропорційна до змістового тезаурусу тексту-джерела та організації комунікативного процесу (передачі повідомлень). Справедливо зазначається, що трансляція певної інформації, так само і процес відтворення тексту, потребує впорядковування тому, що лише таким чином формується установка на смисл. Наявність коду допомагає встановлювати певний - не лише зовнішній, але й внутрішній - порядок експлікації художньої (музичної) ідеї, створювати новий інтрепретативний профіль тексту як власний авторський внесок до структури художньої комунікації.

Якщо розглядати естрадне вокальне виконавство як різновид музичного тексту, що передбачає особливі прояви інтертекстуальності, 
то в ньому можна знайти нашарування художньо-видових рядів, виразових форм та значень, художньо-мовних засобів та інтерпретативних прийомів. 3 боку специфічних завдань художньої комунікації воно постає узагальненою формою музично-артистичної діяльності, що навіть здатна претендувати на універсальність та володіє власними сценічно-постановочними канонами, поповнює когорту «вічних образів» $\mathrm{i}$ «вічних тем», отже ціннісних концептів культури, але в їх новому популяризованому розумінні. В даній галузі також існують взірцеві композиційні та семантичні моделі, наслідування яких є визнаним способом долучитися до естрадного вокально-виконавського професіоналізму.

На думку I. Шароєва [10], естрадне мистецтво, усі форми естрадної творчості найтіснішим чином пов'язані з сучасністю, а естрадне мистецтво виправдовує своє призначення тільки тоді, коли узгоджене $з$ ритмом теперішнього в його усуспільненому значенні, занурене до гущини народного життя. Навіть в окремому естрадному номері зберігається історична пам'ять естрадного мистецтва, яке бере початок зі скоморошин та народного гуляння, вбирає музичне начало та зображальні форми, поєднує спів і танець, кіно і цирк, а найголовніше - $є$ своєрідним різновидом театрального мистецтва, тобто також скероване до сценічної завершеності та навіть ритуалізованості. Тому між естрадним мистецтвом та музично-театральними постановками, у тому числі оперними, існують певні інтерпретативно-драматургічні паралелі.

Відомо, що вже в оперних постановках кінця XIX - початку XX століття «на перший план виходить фігура режисера. Режисер часто стає чи не головним з творців оперного спектаклю, про що свідчить і стійкість формулювання «режисерський театр», що все частіше зустрічається і в рецензіях, і в працях мистецтвознавців. Це свідчить про підвищення значення візуально-пластичного компонента в музично-театральному мистецтві, що, втім, не гарантує драматургічної, художньої переконливості постановки і не завжди може бути протиставлено традиціям «концерту в костюмах». Способи переосмислення художньої спадщини минулого різноманітні, але саме в XX столітті починає акцентуватися ця сторона існування оперного жанру» $[8,5]$.

Автор наведеного висловлення погоджується з тим, що варіативність закладена в самій природі оперного спектаклю, а оперний текст має ту смислову рухливість, яка дозволяє йому зберігати життєздатність в мінливих соціокультурних історичних умовах, отже оперні 
виконавці мають право на вільну відкриту інтерпретацію - на переосмислення музично-театрального тексту. Тому є плідним «вивчення оперного твору не тільки в межах традиційного музикознавчого «аналізу по партитурі», а й на основі його сценічної історії, живого виконавського буття, що, таким чином, постає необхідною частиною художнього тексту, також зумовлює активність інтертекстуальних зв'язків, що передбачають інтерпретативні передумови та шляхи реалізації.

Як і в «серйозному» оперному театрі, в розважальній естрадній виставі задіяні певні культурні паттерни та ціннісні парадигми, узгоджені з уявленнями про людину та ії спосіб життя. Вже на рівні репертуарного вибору та при формуванні загального сценарію концертно-сценічної дії встановлюються семантичні відповідності між попередніми та новими формами інтерпретації, що також є виявом інтертекстуальної художньо-виконавської свідомості.

Можна стверджувати, що інтерпретація та інтертекстуальність це дві сфери, з яких виникають і до яких повертаються творча дія, мистецьке осмислення, образна концепція в процесі вироблення цілісної семантики естрадно-концертної програми. Інтерпретація, як це і зазначає Г. Гадамер, передує тексту і визначає його розуміючі властивості; інтертекстульність виводить за межі тексту ті результати осягнення смислу, котрі здатні об’єднуватися у нові інтерпретативні передумови, входити до кодових конфігурацій. Цікаво, що і стосовно оперного тексту у його співвідношенні з інтерпретацією А. Сокольська зауважила: «інтертекстуальність виявляється однією з ключових властивостей оперного тексту, оскільки твори виявляють нові смислові пласти в результаті зіткнення з тим чи іншим міфом. Механізм смислотворення в оперному тексті має інтертекстуальну природу, і редукція до міфу визначає як традиції прочитання твору, так і новизну можливих інтерпретацій. Редукція до міфу, по суті, є одним з найбільш явних показників умов комунікативної ситуації» [8, 157]. У нашому випадку, тобто у сфері естрадно-вокальної виконавської творчості у іiї театралізовано-постановочному вигляді, міфологізація стосується постаті співака, цієї центральної «дійової особи» концертної програми, який опрацьовує певний імідж не стільки заради «зірковості», скільки з метою досягти граничної художньої переконливості, зливаючи ролеву поведінку на сцені з відтворенням образу самого себе - такого, яким бажають бачити, сприймати, оцінювати його глядачі/слухачі, широка аудиторія. Тому це образ не вигаданого 
персонажу, а близької за часом та сенсом життя людини, водночас не такої, якою вона є в буденно-ужитковому плані, а такої, якою вона може і повинна бути в віртуальній художній реальності, - естетично піднесеної та морально виваженої.

Тому головними складовими інтертекстуальної сфери, що формується навколо естрадної вистави та зумовлює спеціальний режисерський інтерес до неї, є семантичні позиції або «точки зору» стосовно співака як особистісного осередка, змістового стрижня всієї рухливої картини естрадно-сценічної дії.

Саме ці семантичні чинники упорядковують та приводять до цілісного художнього результату усі структурні показники естрадного виступу. 3 іншого боку, вокальне естрадне мистецтво, навіть при переважанні сольного начала та традиційної номерної концертної форми, прагне до театралізованої квазі-сюжетної побудови, яка дозволяє поглиблювати, збагачувати сценічні хронотопи, відкривати їх нові смислові об'єми, тобто підсилювати рольові аспекти сценічного образу. Провідними формами інтерпретації, що розвиваються у певній послідовності та впливають одна на одну, розширюючи та зміцнюючи коло професійних завдань, в сфері естрадного вокального мистецтва є концертно-виконавська - вокально-артистична - режисерськопостановочна, які поєднані поняттям сценічної дії, спільної для всіх видів інтерпретативної праці, також всі мають спиратися на єдиний образ «людини співочої». Завдяки магістральному положенню творчої особистості співака-соліста, що мовби притягує до себе й утримує усі нитки дії, саме від нього залежить надання естрадній програмі характеру «виконавсько-режисерського театру». Це поняття цілком ймовірне, враховуючи, що вже закріпилося в професійній естрадно-музичній термінології поняття «виконавської пісні», «авторсько-виконавської поезії тощо. А категорія виконавської форми є достатньо широкою для того, щоб об’єднати собою усі різновиди сценічної творчості...

Герменевтичний підхід до текстологічних умов естрадної вокальної творчості дозволяє наблизитися до питань про пріоритет особистості співака остільки, оскільки вказує на відповідність художнього змісту виконуваних творів сценічному персонажу-образу в його музичній оформленості та виразності. Вокальний голос - спів - умовна сценічна роль, відповідна до змісту пісні, виявляють внутрішню психологічну межу сценічного простору як художнього та зі спеціальними художніми намірами створеного. 3 їх допомогою виконавська інтерпретація здійснює семантичне кодування - відзначає провідні 
символи, зав’язує головні символічні вузли, що допоможуть здійснитися прихованому психологічному сюжету, увиразнити ключові переживання, музично підвищити значення людської мови.

За спостереженнями деяких дослідників, зокрема Н. Маркарьян та А. Буданова, наприкінці XX століття в європейському театрі затверджується принцип «поетичної режисури», поетичної режисерської естетики, що приходить на заміну прозового методу та доводить можливість гармонії «між конкретикою факту і багатозначністю його емоційного осмислення, між ланками подієвого ряду і безмежністю людського космосу в ряду узагальнюючому... Музичне рішення омиває тут сценічну дію з усіх боків, народжуючи іiі і несучи «вгору», змушуючи постановку жити за законами життя людської особистості 3 усіма ії інтелектуальними й емоційними протиріччями і складнощами...» $[4,368]$.

Причиною таких інтерпретативних змін у режисерському ставленні до естетичних настанов музичного театрує те, що театр повертається до живої людини з іiї «душевними і духовними устремліннями, болем і надією, відчаєм і радістю», до сьогоднішньої людської особистості. навіть у бертманівських постановках у «Гелікон-Опера» використані такі сценічні постановочні й акторські завдання, які, незалежно від історичного часу текстового першоджерела, відображають сучасні уявлення про людську екзистенцію, а режисерські метафори ведуть до підсиленої трансляції «енергетики чуттєвості», «експресії складного емоційного світу людського існування» без розподілу на позитивних і негативних персонажів. Причому яскрава театральність домінування видовищного начала, укрупнення, певна плакатність висловлюваних почуттів зсувають межу високого академічного мистецтва у бік «маскультурних асоціативних констант».

А. Буданов справедливо вказує, що Д. Бертман постійно вводить елементи гри, карнавалізації, гротеску, але, поруч з цим, глибоко виявляє трагедійний зміст буття, нагадує «вічну тему» моральної боротьби, протистояння добра і зла. Він не лише користується фресковими образами, але й деталізує психологічні стани, досягаючи ліричної експресії вокального звучання, наголошує на майстерності вокального інтонування як головного способу відтворення особистісних почуттів [2].

В цілому визначення інтерпретативних принципів естрадної вокальної творчості як необхідної складової частини естрадного сценічного мистецтва відкриває нові критерії оцінки і структурування ви- 
конавської форми як синтетичного функціонального феномена, що ініційований особливими театральними аспектами естрадно-концертної програми. Зокрема з певних семантичних позицій в новому світлі постає порівняльне вивчення вербальних, музичних і жестикулятивно-пластичних (хореографічних) модусів естрадно-пісенного комплексу, що виявляються майже рівнодіючими у загальному концепційному рішенні естрадно-пісенної програми. Водночас найбільш безпосередньо сутність характеру та смислове виконання творчої дії розкриваються на рівні музичної стилістики (звичайно у її союзі з поетичними словесним матеріалом, але й як самостійного знакового утворення). Засоби виконавської (концертно-виконавської - режисерської) інтерпретації досягають завершеності та остаточної образної верифікації у музичній формі, тобто у логіці музичного звучання та на засадах музично-знакового кодування. Саме музичне звучання є ліричними осередком естрадної дії та головним аргументом на користь ії головного «героя».

Наукова новизна роботи полягає у розкритті значення явищ інтерпретації та інтертекстуальності в сфері вокально-естрадного виконавства, у визначенні провідних форм інтерпретації в галузі естрадного мистецтва як театралізованої сценічної артистичної діяльності, у виявленні магістральної ролі особистості естрадного співака в організації інтерпретативної семантичної цілісності художньої форми естрадної вистави.

Висновки. Вокально-естрадне виконавство має складну текстологічну організацію, що зумовлена особливою природою естрадного мистецтва. Воно передбачає високу інтертекстуальну активність провідної «дійової особи» - артиста-соліста, який стає семантичним стрижнем естрадно-сценічної дії, суміщає декілька інтерпретативних функціональних планів, сприяє переродженню естрадної програми у сучасну квазі-сюжетну виставу з поетизованим образом людини у композиційному осередку.

Музична концепція стає основою всього естрадно-сценічного розважально-ігрового процесу ще і тому, що надає йому нової етичної ваги. Вона передбачає зв’язки зі сценічно-видовищною формою, виправданість з боку умовного сюжетного змісту естрадної вистави, особливої синтетичної виконавської стилістики, тобто вимагає підтримки та смислового резонансу з боку інших художньо-виразових рядів вистави. Але лише вона дозволяє співакам передавати образні інтенції пісенних творів та власних інтерпретативних передчуттів, де- 
монструвати досконалість артистичного втілення характеру удаваного персонажу і тонке відчуття загального ритму вистави, інтонаційну гнучкість у відтворенні музично-поетичної риторики та високий рівень художньої емпатії.

\section{СПИСОК ЛІТЕРАТУРИ}

1. Барт Р. Избранные работы. Семиотика. Поэтика / [сост., общ. ред. и вступ. ст. Г. К. Косикова]. М.: Прогресс, 1994. 616 с.

2. Буданов А. Становление театра «Геликон-опера»: дис. ... канд. искусствоведения: спец. 17.00.01 - театральное искусство. М., 2011. 271 с.

3. Кадцын Л. Массовое музыкальное искусство XX столетия (эстрада, джаз, барды и рок в их взаимосвязи): учеб. пособие. Екатеринбург, 2006. $424 \mathrm{c}$.

4. Маркарьян Н. Режиссура и дирижирование: проблемы взаимодействия в оперном театре XX - начала XXI веков: дис. ... докт. искусствоведения; спец.: 17.00.01 - театральное искусство. М., 2006. 399 с.

5. Муратов М. Эстрада как феномен массовой культуры: автореф. дис. ... канд. филос. наук. Казань, 2005. 36 с.

6. Рубб А. Феномен эстрадной режиссуры: опыт исследования. М.: Луч, 2001. $230 \mathrm{c}$.

7. Силантьева И. Проблема перевоплощения исполнителя в вокальносценическом искусстве: автореф. дис. ... доктора искусствоведения: 17.00.02. М., 2008. $47 \mathrm{c}$.

8. Сокольская А. Оперный текст как феномен интерпретации: дис. ... канд. искусствоведения: спец.: 17.00.02 - музыкальное искусство. Казань, 2004. 163 c.

9. Чугунов Ю. Эстрадно-джазовый вокал. Джазовая мозаика / ЗАО РИФМЭ. М., 1997. С. 72-78.

10. Шароев И. Режиссура эстрады и массовых представлений: учебник для студентов театральных высших учебных заведений. Изд. 2-е, перераб. М.: Гитис, 1992. 434 с.

\section{REFERENCES}

1. Bart, R. (1994). Selected works. Semiotics. Poetics: [comp., Society. Ed. and entry. Art. G. K. Kosikova]. Moscow: Progress [in Russian].

2. Budanov, A. (2011). The formation of the theater «Helikon-Opera»: Candidate's thesis. M. [in Russian].

3. Kadtsyn, L. (2006). Mass musical art of the XX century (variety, jazz, bards and rock in their relationship): Textbook. allowance. Ekaterinburg [in Russian].

4. Markar'yan, N. (2006). Directing and conducting: problems of interaction in the opera theater of the XX - beginning of the XXI centuries: Doktor's thesis. M. [in Russian] 
5. Muratov, M. (2005). Estrada as a phenomenon of mass culture: the author's abstract. Candidate's thesis. Kazan [in Russian].

6. Rubb, A. (2001). Phenomenon of variety directing: the experience of research. M.: Ray [in Russian].

7. Silanteva, I. (2008). The problem of reincarnation of the performer in the vocal and theatrical art: the author's abstract. Doktor's thesis. Moscow [in Russian].

8. Sokolskaya A. (2004). Opera text as a phenomenon of interpretation: Candidate's thesis. Kazan [in Russian].

9. Chugunov, U. (1997). Variety-jazz vocal // Jazz mosaic / ZAO RIFME. M. P. 72-78 [in Russian].

10. Sharoev, I. (1992). Directing the stage and mass performances. Textbook for students of theatrical higher educational institutions. Izd-e 2nd, revised. M.: Gitis [in Russian].

Стаття надійшла до редакції 15.03.2017

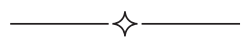

УДК 781.1:78.071.1

\author{
Анна Павловна Копейка \\ аспирантка кафедры истории музыки \\ и музыкальной этнографии \\ Одесской национальной музыкальной \\ академии имени А. В. Неждановой \\ anna.kopejka@gmail.com
}

\title{
ЧИСЛО КАК ФОРМООБРАЗУЮЩИЙ ПРИНЦИП МУЗЫКАЛЬНОЙ КОМПОЗИЦИИ
}

\begin{abstract}
Цель работы. Исследование посвящено некоторым аспектам взаимодействия музыки и математики, а именно - композиторским замыслам, основу которых составляют фундаментальные мировые константы (такие как число пи и число Эйлера) либо статистические данные, некоторым образом воплощенные авторами в звуковой ткани их произведений. Помимо диалога музыкантов с математикой в статье приводится пример обратного диалога (математические исследования Леонарда Эйлера в области музыки) и рассматривается возникающий в связи с этим вопрос о диссонансе в музыке. Методология состоит в использовании компаративного, аналитического, историко-логического методов. Научная новизна работы заключается в расширении бытующих представлений о сопутствующей роли математической составляющей в процессе композиторского творчества до уровня, когда она становит-
\end{abstract}

(C) Копейка А. П., 2017 